\title{
Removal of Lead and Iron Ions by Vegetable Biomass in Drinking Water
}

\author{
Ryoma Bun-eI ${ }^{1}$, Naohito Kawasaki ${ }^{1}{ }^{*}$ Fumihiko OGATA $^{1}$, Takeo NaKamura ${ }^{1}$, \\ Katsuyori AochI ${ }^{2}$ and Seiki TANADA ${ }^{1}$ \\ ${ }^{1}$ School of Pharmacy, Kinki University \\ (3-4-1, Kowakae, Higashi-Osaka, Osaka 577-8502, JAPAN) \\ ${ }^{2}$ Tokyo Deititian Academy \\ (2-23-11, Ikejiri, Setagaya-ku, Tokyo 154-8544, JAPAN)
}

Accepted April 20, 2006 (received for review March 9, 2006)

\begin{abstract}
Vegetable biomass available in all regions of the world was focused on for the purposes of effectively utilizing food wastes, attempting to reduce the emission of carbon dioxide, and developing simple water treatment techniques in developing country. In this study, the adsorption characteristics of heavy metal ions onto vegetable biomass as bean curd lees (BC), corn cobs (CO), and wheat bran (WB) were investigated. In single solution system, larger amounts of iron ion were adsorbed onto $\mathrm{BC}$ than onto $\mathrm{CO}$ and $\mathrm{WB}$. Iron and lead ions were also found to compete in adsorption to $\mathrm{BC}$ in binary solution system. Furthermore, the amounts of the heavy metal ions adsorbed depended on the protein content of the vegetable biomass. However, because the vegetable biomass is rich in nutrients, they are likely to render drinking water treated with them liable to putrefaction. Although viable bacterial counts increased in water with the vegetable biomasses added, the water is considered suitable for drinking for $48 \mathrm{~h}$ or less after the treatment.
\end{abstract}

Key words: vegetable biomass, lead, iron, adsorption, viable bacterial count

\section{Introduction}

The Food Recycling Law took effect in 2001, making food waste recycling mandatory. Food wastes are used for compost, feed, soil conditioner, and so on. The amount of world production is 204,266 thousands ton/year for soybeans, 721,379 thousands ton/year for corn, and 627,131 thousands ton/year for wheat. Consequently, bean curd lees (BC), corn cobs (CO), and wheat bran (WB), which are their residues, are discarded in large amounts. When they are incinerated, they emit huge amounts of carbon dioxide. Because carbon dioxide contributes to global warming most, it is desirable to reduce its emission as much as possible. It is keenly desired to develop technologies for the effective use of vegetable biomass for zero emission (1-3).
Lead has been used for water pipes in Japan, because it is low in cost and easy to process. Lead content was prescribed to " $10 \mu \mathrm{g} / \mathrm{L}$ or less" as a city water quality standard in 2003. Lead dissolved in city water has become a social issue since it was made known to the public. Lead accumulates in the body and manifests such chronic toxicity as intellectual disturbance in fetuses and infants. On the other hand, iron pipes may release corroded iron in water. Especially, chlorine added to city water as a germicide, oxidizes and corrodes iron. The iron content is prescribed to "300 $\mu \mathrm{g} / \mathrm{L}$ or less" as a city water quality standard. Iron overload is known to cause circulatory disorders, vomiting, bleeding, and so forth. It is desirable to remove iron ions from drinking water. In Tanzania, for example, lead and iron ion contents have been reported to be 40 -

\footnotetext{
*Correspondence to: Naohito KAWASAKI, School of Pharmacy, Kinki University, 3-4-1, Kowakae, Higashi-Osaka, Osaka 577-8502, JAPAN

E-mail:kawasaki@phar.kindai.ac.jp
} 
$8580 \mu \mathrm{g} / \mathrm{L}$ and 6-990 $\mu \mathrm{g} / \mathrm{L}$, respectively (4). Moreover, water for daily life is contaminated with heavy metal ions in developing country including Bangladesh (5-7). If simple techniques practicable in developing county are developed, the techniques could be provided to them.

This study aims to develop technologies for a recycling society and prevent health disorders due to heavy metal ions. Vegetable biomass of three different kinds were examined to find how suitable they are as adsorbents for iron and lead ions and study the effective utilization of the biomass for decreasing carbon dioxide emission, using the data of crude protein and crude fat contents, carbon contents, adsorption isotherms, and viable bacterial counts in water treated with vegetable biomass.

\section{Experimental}

\subsection{Materials}

$\mathrm{Pb}\left(\mathrm{NO}_{3}\right)_{2}$ and $\mathrm{Fe}\left(\mathrm{NO}_{3}\right)_{3}$ (both by Wako Pure Chemical Industries Co., Ltd.) were used for the standard solutions of lead and iron ions, respectively. As adsorbents, the following were used: bean curd lees (BC) discarded from tofu manufacturing process and dried, corn cobs (CO) prepared from commercially available corns and dried, and commercially available wheat bran (WB).

\subsection{Amount of Lead and Iron Ion Adsorbed}

In single solution system, adsorbents were added to each solution of different concentrations of $\mathrm{Fe}\left(\mathrm{NO}_{3}\right)_{3}$ or $\mathrm{Pb}\left(\mathrm{NO}_{3}\right)_{2}$ at a ratio of $50 \mathrm{mg}$ to $500 \mathrm{~mL}$. In binary solution system, adsorbents were added to solution of different concentrations of both $\mathrm{Fe}\left(\mathrm{NO}_{3}\right)_{3}$ and $\mathrm{Pb}\left(\mathrm{NO}_{3}\right)_{2}$ at a ratio of $50 \mathrm{mg}$ to $500 \mathrm{~mL}$. The liquids were shaken at $100 \mathrm{rpm}$ at $25^{\circ} \mathrm{C}$ for $24 \mathrm{~h}$ and filtered through membrane filter. The concentration of iron and lead was used to measure ortho-phenantrolin method or a scanning lead analyzer HAS-1000 (The HACH Company), respectively. The amount adsorbed was calculated by Eq. [1] using the initial and equilibrium concentrations:

$$
\mathrm{V}=(\mathrm{Co}-\mathrm{C}) \cdot 500 / 1000 / \mathrm{W} \quad \text { Eq. [1] }
$$

where $\mathrm{V}$ is the amount adsorbed $(\mu \mathrm{g} / \mathrm{g})$, Co is initial concentration $(\mu \mathrm{g} / \mathrm{L}), \mathrm{C}$ is equilibrium concentration $(\mu \mathrm{g} / \mathrm{L})$, and $\mathrm{W}$ is the weight of an adsorbent $(\mathrm{g})$.

\subsection{Components of Food Components}

Crude protein content was calculated using the semimicro Kjeldahl method (8). First, $0.02 \mathrm{~g}$ of precisely weighed sample was placed in a decomposition flask. To this were added $0.5 \mathrm{~g}$ of a decomposition promoter $\left(\mathrm{K}_{2} \mathrm{SO}_{4}: \mathrm{CuSO}_{4} \cdot 5 \mathrm{H}_{2} \mathrm{O}=10: 1\right), 3 \mathrm{~mL}$ of concentrated sulfuric acid, $1 \mathrm{~mL}$ of $30 \mathrm{w} / \mathrm{v} \%$ hydrogen peroxide solution and $25 \mathrm{~mL}$ of $30 \mathrm{w} / \mathrm{v} \%$ sodium hydroxide solution. Then steam distillation was started, and $100 \mathrm{~mL}$ of distillate was taken to be the sample solution. A solution prepared by adding $15 \mathrm{~mL}$ of $4 \mathrm{w} / \mathrm{v} \%$ boric acid solution and a few drops of bromcresol green and methyl red was used for the adsorbing solution. The test solution was titrated with $0.025 \mathrm{~mol} / \mathrm{L}$ sulfuric acid solution, and a separate blank experiment was performed using distilled water. Protein content was calculated using Eq. [2]

$$
\mathrm{P}=0.7003 \cdot(\mathrm{a}-\mathrm{b}) \cdot 100 / \mathrm{M} \cdot 6.25 \quad \text { Eq. [2] }
$$

where $\mathrm{P}$ is the crude protein content (\%), a is the sulfuric acid titer $(\mathrm{mL})$ required in the main experiment, $\mathrm{b}$ is the sulfuric acid titer $(\mathrm{mL})$ required in the blank experiment, $\mathrm{M}$ is the sample weight $(\mathrm{mg})$ and 6.25 is the nitrogen coefficient.

A Soxhlet fat extraction apparatus for extraction with ether was used to determine crude fat (9). A biomass accurately weighed to $5 \mathrm{~g}$ was placed in a filter paper cylinder and diethyl ether was poured into the flask; extraction was performed for about $6 \mathrm{~h}$. The flask was dried at $98-100^{\circ} \mathrm{C}$ for about 1 hour, left to cool in a desiccator, and weighed. The amount of crude fat was calculated by Eq. [3].

$$
\mathrm{F}=(\mathrm{A}-\mathrm{B}) \cdot 100 \quad \text { Eq. [3] }
$$

where $\mathrm{F}$ is the amount of crude fat (\%), $\mathrm{A}$ is the weight (g) of the flaks after fat extraction and drying, and B is the weight $(\mathrm{g})$ of the flask with boiling tips.

\section{Results}

\section{$3 \cdot 1$ Components of Vegetable Biomasses}

Table 1 shows the carbon content, crude fat content, total nitrogen, and crude protein contents of $\mathrm{BC}, \mathrm{CO}$, and WB. The carbon content of the three vegetable biomass ranged $41.2 \sim 46.4 \%$; $\mathrm{BC}$ was the highest in carbon content. On the other hand, their crude fat content ranged 0.6 to $13.7 \%$, depending very much on the kind of biomasses. Especially, BC showed the highest 
Table 1 Percentage of Carbon, Lipid, Nitrogen and Protein in Vegetable Biomass.

\begin{tabular}{ccccc}
\hline Samples & $\begin{array}{c}\text { Carbon content } \\
(\%)\end{array}$ & $\begin{array}{c}\text { Crude fat } \\
\text { Content }(\%)\end{array}$ & $\begin{array}{c}\text { Total nitrogen } \\
(\%)\end{array}$ & $\begin{array}{c}\text { Crude protein } \\
\text { content }(\%)\end{array}$ \\
\hline BC & 46.4 & 13.7 & 4.1 & 25.6 \\
CO & 41.2 & 0.6 & 0.6 & 3.5 \\
WB & 42.7 & 2.3 & 3.0 & 19.0 \\
\hline
\end{tabular}

crude fat content. Their total nitrogen and crude protein ranged $0.6 \sim 4.1 \%$ and $3.5 \sim 25.6 \%$, respectively. $\mathrm{BC}$ was far higher in them than $\mathrm{CO}$ and WB.

\subsection{Adsorption Isotherm of Lead and Iron Ions onto Vegetable Biomass}

Figure 1 shows the adsorption isotherms of lead and iron ions onto the three kinds of vegetable biomass in single solution system. The adsorption isotherms depended very much on the kind of the biomass. The amount of iron ion adsorbed increased in an ascending order of $\mathrm{WB}<\mathrm{CO}<\mathrm{BC}$ when the equilibrium concentration was $150 \mu \mathrm{g} / \mathrm{L}$ or lower; it increased in an ascending order of $\mathrm{CO}<\mathrm{WB}<\mathrm{BC}$ when the concentration was $150 \mu \mathrm{g} / \mathrm{L}$ or higher; and there was no iron ion adsorption to WB when the concentration was $100 \mu \mathrm{g} / \mathrm{L}$ or lower.

Figure 2 shows the adsorption isotherms of iron ion for the three kinds of vegetable biomass in binary solution system. The adsorption isotherms in binary solu-

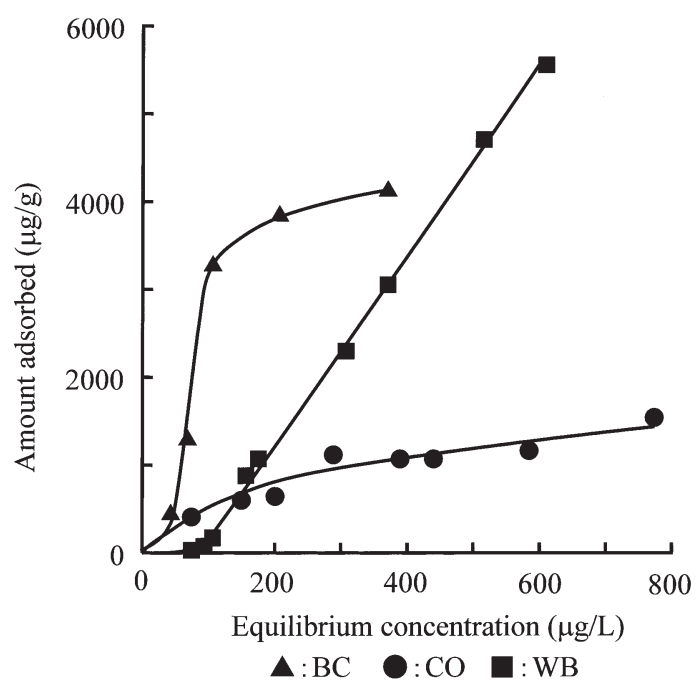

Fig. 1 Adsorption Isotherm of Iron onto Vegetable Biomass in Single Solution System. tion system resembled those in single solution system. The amount of iron ion adsorbed increased in an ascending order of $\mathrm{CO}<\mathrm{WB}<\mathrm{BC}$. WB did not adsorb any iron ion when the equilibrium concentration was $100 \mu \mathrm{g} / \mathrm{L}$ or lower.

Figure 3 shows the adsorption isotherms of lead and iron ions in single and binary solution systems. A comparison of lead and iron ion adsorption between the two solution systems showed both ions were adsorbed more in single solution system than in binary solution system when their equilibrium concentrations were high.

Figure 4 shows the adsorption isotherms of lead ion onto $\mathrm{BC}$ determined at 15 and $25^{\circ} \mathrm{C}$. Lead ion adsorption to $\mathrm{BC}$ was little affected by temperature.

\subsection{Viable Bacterial Counts in Water Treated with Vegetable Biomass}

The viable bacterial counts, which are measured for food poisoning, in water kept at 15 or $25^{\circ} \mathrm{C}$ was deter-

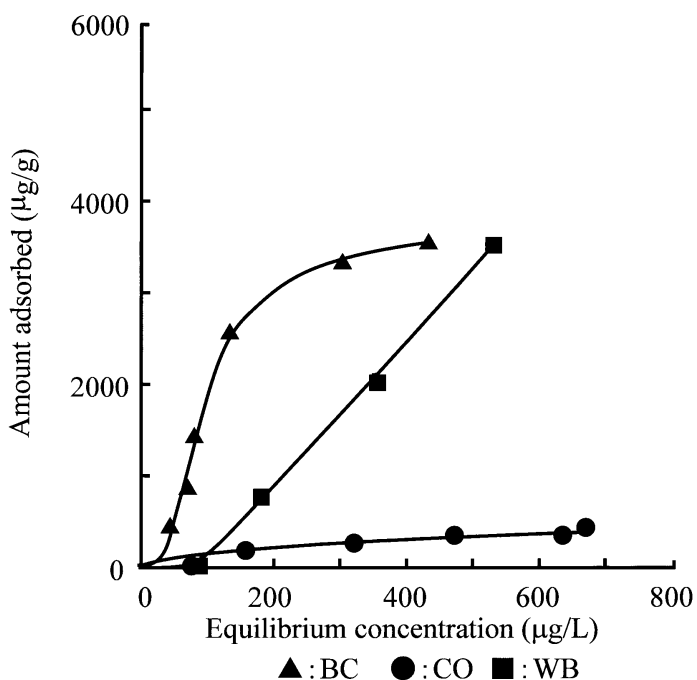

Fig. 2 Adsorption Isotherm of Iron onto Vegetable Biomass in Binary Solution System. 


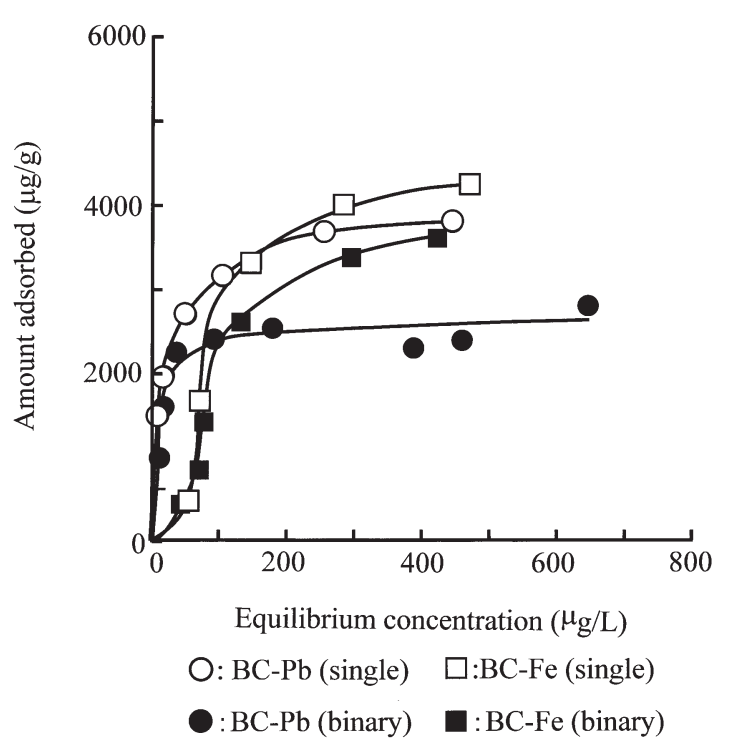

Fig. 3 Adsorption Isotherms of Iron and Lead Ions onto BC in Single and Binary Solution Systems.

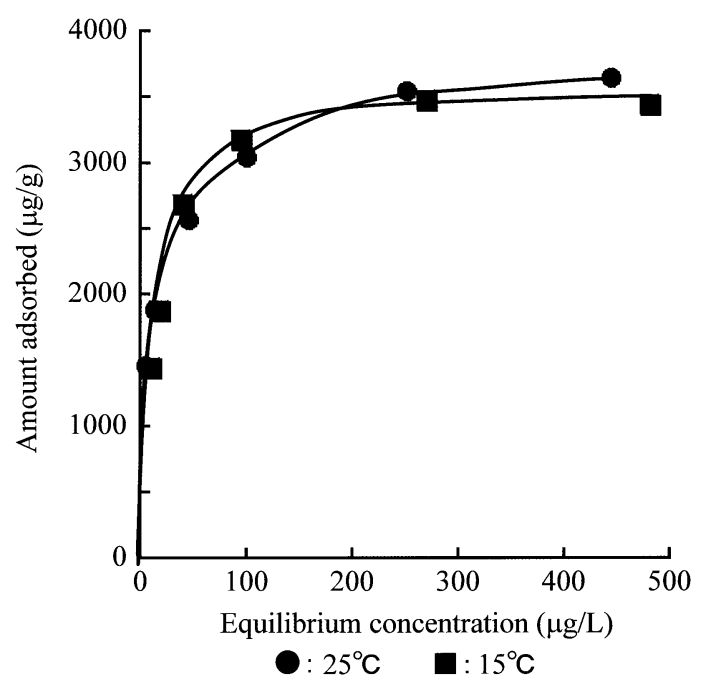

Fig. 4 Adsorption Isotherm of Lead onto $\mathrm{BC}$ at Different Temperatures.

mined after the addition of BC, CO, and WB. Table 2 shows the result. Those increased to 2569 for $42 \mathrm{~h}$ at $15^{\circ} \mathrm{C}$ after $\mathrm{BC}$ addition; it exceeded 7380 for $36 \mathrm{~h}$ at $25^{\circ} \mathrm{C}$. When WB or $\mathrm{CO}$ was added, the viable bacterial counts exceeded 5000 for $36 \mathrm{~h}$ at $15^{\circ} \mathrm{C}$ after the addition and $24 \sim 36 \mathrm{~h}$ at $25^{\circ} \mathrm{C}$.

\section{Discussion}

Carbon content ranged $41.2 \sim 46.4 \%$ among the
Table 2 Viable Bacterial Counts in Water Treated with Vegetable Biomass.

\begin{tabular}{rrrrrrr}
\hline Time & \multicolumn{2}{c}{$\mathrm{BC}$} & \multicolumn{2}{c}{$\mathrm{CO}$} & \multicolumn{2}{c}{ WB } \\
(h) & $15^{\circ} \mathrm{C}$ & $25^{\circ} \mathrm{C}$ & $15^{\circ} \mathrm{C}$ & $25^{\circ} \mathrm{C}$ & $15^{\circ} \mathrm{C}$ & $25^{\circ} \mathrm{C}$ \\
\hline 0 & 4 & 3 & 1 & 1 & 0 & 1 \\
12 & 26 & 7 & 7 & 21 & 3 & 3 \\
18 & 46 & 186 & 91 & 906 & 17 & 29 \\
24 & 159 & 2660 & 3460 & $>7380$ & 330 & 640 \\
36 & 909 & $>7380$ & $>7380$ & $>7380$ & $>7380$ & $>7380$ \\
42 & 2569 & $>7380$ & $>7380$ & $>7380$ & $>7380$ & $>7380$ \\
\hline
\end{tabular}

three kinds of vegetable biomass, of which $\mathrm{BC}$ was the highest. The incineration of vegetable biomass is thought to emit large amounts of carbon dioxide. On the other hand, $\mathrm{BC}$ was higher in total nitrogen and crude protein than $\mathrm{CO}$ and WB. Coffee grounds have been reported to depend on their protein for lead ion removal (10). Hence, BC is surmised to be high in iron ion adsorption.

In single solution system, the amount of iron ion adsorbed increased in an ascending order of $\mathrm{WB}<\mathrm{CO}<\mathrm{BC}$ when the equilibrium concentration was $150 \mu \mathrm{g} / \mathrm{L}$ or lower and in an ascending order of $\mathrm{CO}<\mathrm{WB}<\mathrm{BC}$ when the concentration was $150 \mu \mathrm{g} / \mathrm{L}$ or higher. Iron ion adsorption onto the vegetable biomass in binary solution system resembled that in single solution system. Iron ion concentration is prescribed to 300 $\mu \mathrm{g} / \mathrm{L}$ or less as a city water quality standard in Japan. Hence, $\mathrm{BC}$ is considered far more suitable for iron ion removal than $\mathrm{CO}$ or WB. Stated another way, BC adsorbs the largest amount of iron ion among the three vegetable biomass; $\mathrm{CO}$, which was the lowest in total nitrogen and crude protein content, adsorbed the least amount of iron ion.

A comparison of lead and iron ion adsorption to $\mathrm{BC}$ between the single and binary solution systems showed both ions were adsorbed more in single solution system than in the binary solution system throughout the ranges of equilibrium concentrations. The result is deemed to indicate that lead and iron ion adsorptions to $\mathrm{BC}$ are competitive. Because amounts of both ions adsorbed to the vegetable biomass increased with increasing contents of total nitrogen and crude protein, the capacity of the vegetable biomass to remove lead and iron ions was judged to depend on the protein content of food wastes. 
Generally speaking, the heat of physical adsorption is far smaller than that of chemical adsorption. An adsorbent with minimum dependence on temperature is desirable for good performance under a wide range of temperatures. Because the adsorption isotherms of lead ion onto $\mathrm{BC}$ at 15 and $25^{\circ} \mathrm{C}$ showed iron adsorption was little influenced by temperature, $\mathrm{BC}$ was judged usable over the temperature range of 15 to $25^{\circ} \mathrm{C}$.

$\mathrm{BC}, \mathrm{CO}$, or WB was added to water, which was kept at 15 or $25^{\circ} \mathrm{C}$ to measure viable bacterial counts. Water with $\mathrm{BC}$ added did not exceed 5000 in the viable bacterial counts, which is generally said to be a level to cause food poisoning, in about $42 \mathrm{~h}$ at $15^{\circ} \mathrm{C}$ but exceeded 5000 for $36 \mathrm{~h}$ at $25^{\circ} \mathrm{C}$. This result indicated that the viable bacterial counts are apt to increase with rise in water temperature. In addition, although the viable bacterial counts were found to vary by the kind of biomass, both WB and CO showed similar tendencies. Both biomasses exceeded 5000 for $36 \mathrm{~h}$ at $15^{\circ} \mathrm{C}$ and $24 \sim 36$ $h$ at $25^{\circ} \mathrm{C}$.

\section{Conclusion}

BC, a biomass, was found more suitable for the removal of lead and iron ions from city water than WB and $\mathrm{CO}$, biomasses. In addition, temperatures in a range of $15-25^{\circ} \mathrm{C}$ did not influence lead ion adsorption to bean curd lees and was deemed to be able to remove the ions highly efficiently. Furthermore, because the adsorption of heavy metal ions in drinking water to vegetable biomass was lower in single solution system than in binary solution system, their adsorptions are considered competitive. Iron ion adsorption to vegetable biomass is related to the protein content of the biomass; the higher the protein content of plant biomass, the greater the adsorption. However, because the total plate count of water with plant biomass added increased faster than that of ordinary drinking water, the former is judged suitable for drinking for $48 \mathrm{~h}$ or less.

\section{References}

1. M. MAEDA and T. IKEDA, Recycling and Material Flow of the World, Polymers for Advanced Technologies, Vol. 11, 388-391 (2000).

2. G. PAULI, How to Compete in the $21^{\text {st }}$ Century-bold Ideas and Concrete Applications-tha Case of Zero Emissions, Chem. Enginer. World, Vol. 32, 81-86 (1997).

3. G. PAULI, Zero Emissions Research Initiative. How to Complete in the Future?, Sangyo to Kankyo, Vol. 36, 107-120 (1997).

4. S.S.S. RWEGOSHORA, Assessment of Water Quality of Selected Water Supply Sources in Tanzania, Int. J. Biochem. Physic., Vol. 11\&12, 1-8 (2003)

5. M.R. ISLAM, P.W. LAHHERMO, R. SALMINIEN, S. ROJSTACZER and V. PEURANIEMI, Lake and Reservoir Water Quality Affected by Metals Leaching from Tropical Soils, Bangladesh, Environ. Geology, Vol. 39, 1083-1089 (2000).

6. M.R. ISLAM, R. SALMINIEN and P.W. LAHERMO, Arsenic and Other Toxic Elemental Contamination of Groundwater, Surface Water and Soil in Bangladesh and Its Possible Effects on Human Health, Environ. Geochem. Health, Vol. 22, 33-53 (2000).

7. S.H. FRISBIE, R. ORTEGA, D.M. MAYNARD and B. SARKAR, The Concentrations of Arsenic and Other Elements in Bangladesh's Drinking Water, Environ. Health Perspect., Vol. 110, 1147-1153 (2002).

8. J.Z. KJELDAHL, Neue Methode Zur Bestimmung des Stickstoffs in Organischen Korpern, Anal. Chem., Vol. 22, 366-382 (1883).

9. F. SOXHET, Die Gewichtsanalytische Bestimmung des Milchfettes, Polytechnisches J., Vol. 232, 461 (1879).

10. T. TOKIMOTO, N. KAWASAKI, T. NAKAMURA, J. AKUTAGAWA and S. TANADA, Removal of Lead Ions in Drinking Water by Coffee Grounds as Vegetable Biomass, J. Colloid Interface Sci., Vol. 254, 17-22 (2002). 